\title{
REVIEW
}

\section{Development and challenges of green food in China}

\author{
Mahmood ul HASSAN ${ }^{1}$, Xin WEN ${ }^{1,2,3}$, Jiuliang XU ${ }^{1,2,3}$, Jiahui ZHONG ${ }^{1,2,3}$, Xuexian LI (ه) $)^{1,2,3}$ \\ 1 Department of Plant Nutrition, The Key Plant-Soil Interaction Laboratory, Ministry of Evironment, China Agricultural University, \\ Beijing 100193, China \\ 2 National Academy of Agriculture Green Development, China Agricultural University, Beijing 100193, China \\ 3 Chinese Academy of Green Food Development, Beijing 100193, China
}

\begin{abstract}
Green food in China refers to a wide array of primary and processed agricultural products that are safe, nutritious and of high quality for human consumption. Green food has been certified and produced following the principle of sustainability since the 1990 s, making historic achievements in providing quality food, protecting the environment, increasing farmer income, and nurturing agricultural brands over the past 30 years in China. Today, the green food industry enters a steady-growth stage in terms of cultivation area, product number and sales. This article summarizes the history of the development of green food in China and current achievements, analyze major challenges that may hamper further development of the industry, and propose strategies to address these challenges, i.e., optimization of the food supply chain, deep food processing, and utilization of food wastes.
\end{abstract}

Keywords green food, food losses, storage, processing, transportation, sustainability

\section{Introduction}

Green food in China refers to uncontaminated, safe, high quality and nutritious food produced by protecting agroecosystems as well as improving the quality of agricultural products and processed food to support sustainable development of the national economy and society ${ }^{[1,2]}$. Green food is defined by the China Green Food Development Center, the Ministry of Agriculture ${ }^{[3]}$. It requires wholesome quality control from field to table and is under strict supervision and regulation during production, processing, packing, storage and transportation. Green food requires high-level reduction in chemical inputs including synthetic fertilizers, pesticides, veterinary

Received September 25, 2019; accepted November 8, 2019

Correspondence: steve@cau.edu.cn drugs and additives to ensure product and environmental safety.

The term "green food" actually covers not only culture of food production, but also considers protection of the environment, economics of stakeholders and social relationships. Green food is usually assumed to be a high-quality food product in China ${ }^{[4]}$ and a vital part of the rural economy that ensures farmer sustainability and survival. Development of green food can increase environmental sustainability of agriculture, reduce the foodborne diseases and increase farm incomes in China $^{[5-10]}$. Green food has a longer certification history and greater popularity than organic food in China as evidenced by increased sales from 403 billion CNY (60 billion USD) in 2017 to 456 billion CNY (64 billion USD) in $2018^{[8,11]}$, whereas the total amount of organic food is very limited due to its high prices.

In prehistory, people after the Stone Age started to develop villages near water sources which led to a greater population and civilization. Later, supplying this civilization become the perpetual challenge for agriculture. In contrast, green culture is sustainable and improves the livelihood of the farmers because it opposes economic restraints and promotes for environmental austerity. Thus, green agriculture is a key component of food production by enhancing the role of peasants in custody of the land and its ecology. In late 1970s and early 1980s, the Chinese government realized the need of an initiative against excessive use of chemical inputs in villages to increase production and to regulate its bad impacts on the environment. Chinese officials were searching for a way to resolve the notion of "high output by high input" involved in grain production ${ }^{[12-14]}$. Accordingly, the Chinese Ecological Agriculture (CEA) was developed ${ }^{[15,16]}$.

In the late $1980 \mathrm{~s}$, a new initiative was undertaken to highlight the environmental protection and quality of products by adopting the idea of pollution-free food production, which was later called green food ${ }^{[5,17,18]}$. It was a CEA objective to improve rural economic conditions 
by preserving the environment through use of chemicals on a sustainable basis. Environmental norms were similar to CEA, to increase organic fertilizers while limiting chemical fertilizer and pesticide application ${ }^{[3,18]}$. One key difference was that CEA focused on endorsing principles and practices to achieve environmentallyfriendly agriculture which provided short-term incentives to CEA growers. While green food production focused on ends instead of means, and ends (food quality, safety, hygiene, packing and labeling as well as export) were controlled by the Ministry of Agriculture locally and at a national level by developing standards. A green food verification committee was launched in Beijing to certify the standards and hence establish the integrity of the green food $\log 0^{[3,5,17]}$. Later, the China Green Food Development Center was established in Beijing and joined the International Federation of Organic Agricultural Movements in 1995. Green Food Standards were developed as A and AA. The A standard was characterized an interim level between the current practice (high-input, agrochemicaldependent production) and organic production (restricted use of chemicals), whereas AA was characterized as full organic production (a complete ban on synthetic chemicals). The A standard products were to be certified every three years, while the AA standard products every year ${ }^{[3,5]}$, but after 2008 no registration was done for AA and only organic food was registered. This paper introduces the current situation of green food in China with a focus on development, contribution, challenges, and prospect for the green food system.

\section{About green food}

Green food products increased rapidly in China since the $1990 \mathrm{~s}^{[4]}$. Green foods encompass a series of raw and processed foods including crop, livestock and aquatic products $^{[8]}$. With ongoing rapid growth of per capita earnings as well as awareness about safe and healthy food in China ${ }^{[19]}$, increasing numbers of people are choosing to purchase green foods. Now certification of green food in China is well established with certification of 4422 firms and 10093 green products in 2017 and a total of 10895 companies covering 25746 green food certified products prior to $2017^{[3,4,8,10]}$. After more than two decades of the development of green food certification, it is important to conduct an assessment for the policy of extension of green food in China and the green food production sector needs special attention (Fig. 1).

\subsection{Green food demand}

Brazil, Russia, India, China and South Africa are large emerging economies with $70 \%$ of the world populations accounting for a huge share of food production and consumption. Sustainable food consumption behavior by consumers is a key factor affecting the food market ${ }^{[10]}$. Limited resources and climate fluctuations mean that the profit-driven agribusiness model is not a sustainable option $^{[20]}$. Green food is essential to feed the everincreasing population of the world (Fig. 2) over the coming generations to insure food security while reducing environmental pressure through economic conditions, social ethics and sustainable development ${ }^{[21-24]}$. Food demand is increasing by up to $60 \%$ to feed an extra 2 billion people in the world with $40 \%$ less water supply available by 2050; production of an additional $1 \mathrm{Gt}$ of cereals and $200 \mathrm{Mt}$ of livestock will damage the environment, without mitigation strategies, by producing $87 \%$ more greenhouse gas (GHG) emission, needing 67\% more cropland, $65 \%$ more water, $54 \%$ more $\mathrm{N}$ and $51 \%$ more $\mathrm{P}$ (Fig. 2). This will be a huge challenge to sustainability for humanity ${ }^{[25]}$. Green food technologies may help to reduce pressure on the environment, as shown in Fig. 2.

Green food is produced under a set of sustainable practices that can reduce the gap in earnings between rural and urban residents by giving $10 \%-50 \%$ prices incentives and reducing inputs costs to boost their economic condition $^{[26,27]}$. Green food has the potential to solve many problems of food security in China and ultimately worldwide. Green food innovation has already resulted in millions of hectares being green food certified and this is increasing rapidly ${ }^{[2]}$. Improving green food production of different sectors will improve the economics of small farms as well as quality of farmland.

\subsection{Green food production}

Green food is a Chinese eco-friendly scheme of food certification that confirms not only production processes but also outcomes. Green food is a set of controlled practices and outcomes, and following standards is necessary for its production ${ }^{[29]}$.

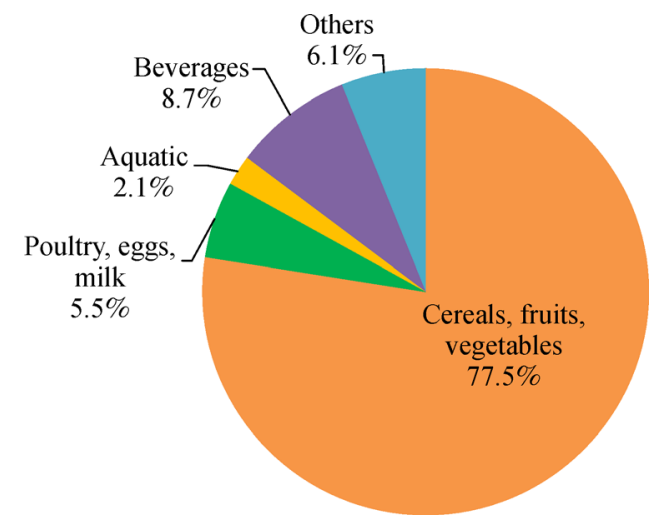

Fig. 1 Green food sectors in China. Data from China Green Food Development Center ${ }^{[11]}$. 


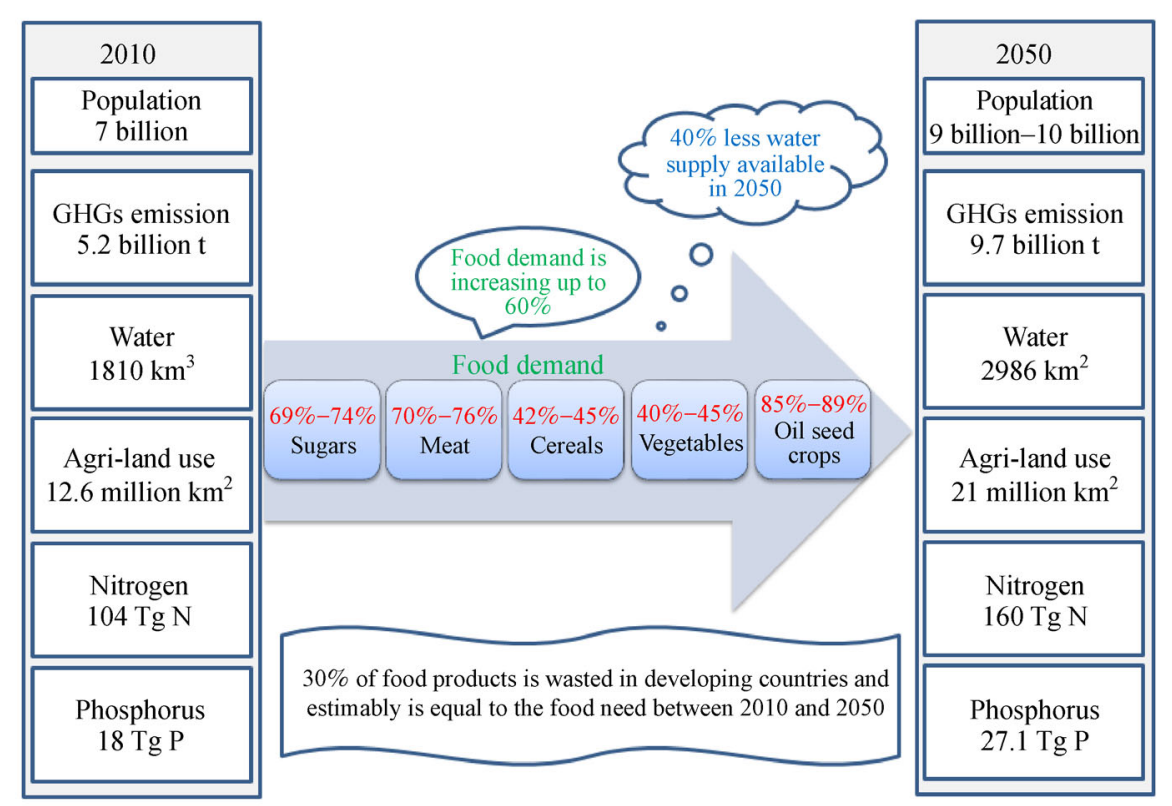

Fig. 2 Global food demand and environmental impacts on food production (comparison of estimated environmental pressure of growing population between 2010 and 2050 and the consequences of increasing demand of green food option).

Planting area must be under the air standards of China. Irrigation and soil must be free from residues of heavy metals (e.g., $\mathrm{Ar}, \mathrm{Cd}, \mathrm{Cr}, \mathrm{Hg}$, and $\mathrm{Pb}$ ).

Treatment and processing water must fulfill the standards of National Drinking Water.

Poisonous pesticides are banned completely, only controlled pesticides usage is permitted

\subsection{Green food development or green growth}

Green food is the best option for sustainability of the environment and this imposes some requirements as shown in Fig. 3 and also the following considerations ${ }^{[20]}$. As consumers become increasingly aware of nutritional quality of the food they consume, national and international regulatory agencies will need to keep pace through the development of rapid and sensitive detection methods, and generation of evidence-based data to assist in the establishment of tolerance criteria for safe levels of chemical toxins in foods.

\subsubsection{Planning}

Planning facilitates the outcomes on a long-term basis; it may not be profitable in the transition period, or not environment friendly or safe from other perspectives, but it will provide benefits over the long-term.

\subsubsection{Policies and standards}

Government policy covers market standardization and promotion of green food production technologies, ensuring practices for green food farming as well as extension services to satisfy consumers' demands by developing safety and quality standards for green foods.

\subsubsection{Eco-environmental responsibilities}

Green food production requires alterations in economic activity patterns to reduce environmental pressure by providing eco-friendly services.

\subsubsection{Economic incentives}

Incentives include targeting support to get desired outcomes and per annum incentive for green food farming innovations, skilled employee, agribusiness and heavy taxes on environment externalities.

\subsubsection{Outcomes}

Special incentives for record green food production as well development of individual green food production expertise are important outcomes. 


\subsection{Contribution of green food}

\subsubsection{Economic contribution}

Farming is the backbone of the economy of agricultural countries, but green food development can serve as a driver of economic development while green growth can expand agricultural performance. Green technologies can regulate excessive consumption and expenditure on water, energy and chemicals and ecologically restore soil quality, nutrient content and water holding capacity. Agri-biodiversity ensures conservation of genetic resources for new crop cultivars and animal breeds ${ }^{[10,22,30]}$.

\subsubsection{Environmental contribution}

Green food production can conserve resources and provide quality produce by protecting the environment on a sustainable basis. Green food development can increase yield via integrated pest, water and nutrient management techniques by conserving biodiversity, drought risks, improved nutrients levels and hydrological function. Seed selection and modified cropping schemes in green growth can mitigate the risks of climate change and reduce crop and farm insurance premiums ${ }^{[30,31]}$.

\subsubsection{Social contribution}

Green food production system will ensure food security, rural development and skilled jobs, and diminish poverty over the long-term by improving livelihood of the producers and health of the consumers. Ecotourism, being the fastest growing tourism sector is a promising route for farmers and local community sustainability ${ }^{[10,22,30,31]}$.

\subsubsection{Science and technology contribution}

Advanced bioinformatics computing technologies and bioproduction implications will pave the way for green food development and reduce the risks of food insecurity and innovations in cropping system, post farming as well as developing green food zones ${ }^{[10]}$. Online marketing is an important option for food sellers and e-commerce giants that is challenging the traditional food retail industry ${ }^{[32,33]}$. Among all countries, China is expected to be the biggest online market in $2019^{[34,35]}$, a trend which started in $2012^{[36]}$ and was encouraged by government by establishing e-marketing policies for agrifood markets ${ }^{[10]}$.

\section{Future challenges}

Agriculture faces complex challenges such as food insecurity, climate change, water availability and squeezing biodiversity in the environment. Innovation in agricultural practice to increase food production while balancing the quality of products and sustainability of the environment is essential as the increasing population increases food demand (Fig. 2; Fig. 3). The major challenges the world will face in upcoming years are outlined below.

\subsection{Waste of uneaten food}

One major challenge is discarded uneaten food that

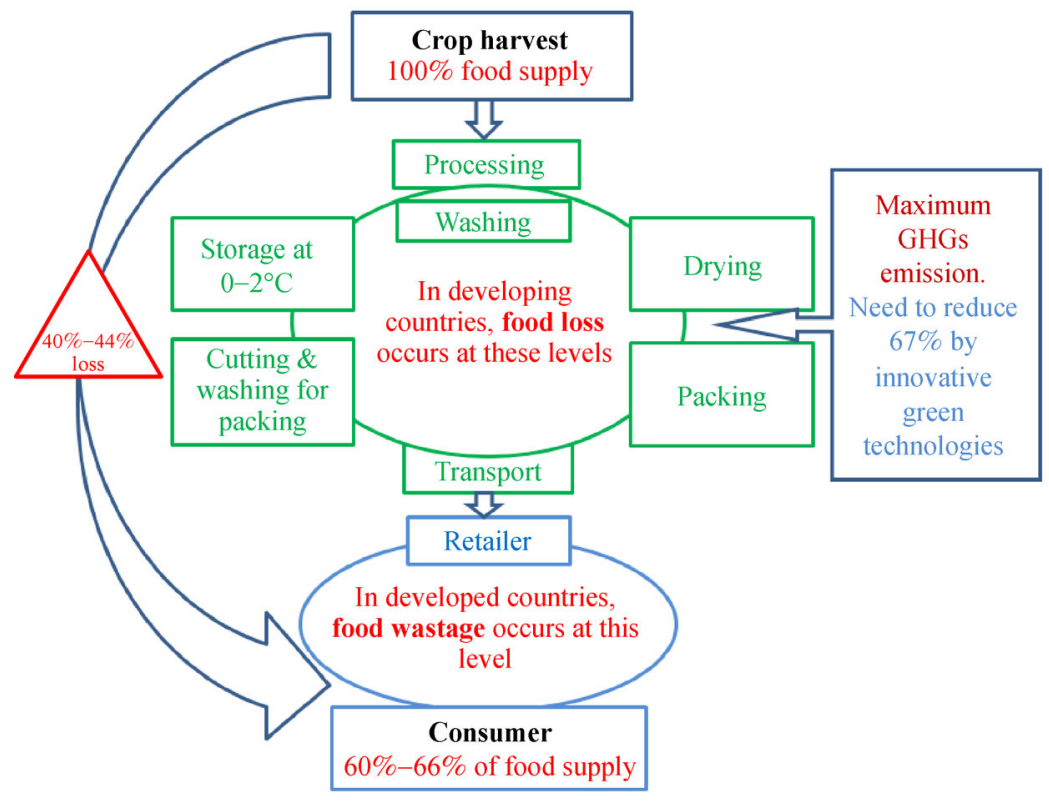

Fig. 3 Food losses in the supply chain from field to consumer. 
contains energy and resources of production including GHG emissions. Globally one third of production is lost as uneaten food loss (i.e., lost before consumption, particularly due to spoilage and leaky supply chains) ${ }^{[37]}$ and represents a huge economic waste ${ }^{[38,39]}$. In the USA, retailer to consumer loss is $30 \%$ for fresh vegetables and $40 \%$ for meat ${ }^{[39]}$. Food waste is a broader term which includes food waste due to human activities as well as pest attack and climate change ${ }^{[40]}$. These includes losses from field to kitchens (end users) as shown in Fig. 2 and Fig. 3 and these losses will be equal to $30 \%$ of production in the coming years ${ }^{[37,41,42]}$. Over $95 \%$ of wasted foods ends up in landfill and affects the climate catastrophically by transformation into $\mathrm{GHGs}^{[43]}$. Notably, replacing animalbased products with plant-based products can increase food availability by allowing resource production from feed to human food ${ }^{[44-49]}$. Improving packaging and infrastructure, and recovering edible losses by integration of green food can reduces these losses in developing countries and is a key strategy to ensure food security $^{[44,49,50]}$, yielding more eaten food per unit of input or pollution output ${ }^{[40]}$. Surveys suggested that global wasted food is enough to feed the people of the world (Fig. 2) ${ }^{[43]}$. Measures to control food loss will help to ensure food security for the world.

\subsection{Climate change}

Climate change is a key risk for global food security. An increase of $1-3^{\circ} \mathrm{C}$ will cause reduced yield and increased inflation in many countries ${ }^{[51]}$. It has direct and indirect impacts on all aspect of food security. It can also spoil food quality, and can impose financial burden in order to avoid food contamination by pests and disease of stored produce. Climate experts are considering the biological and physical changes taking place on earth as a result of climate change and how it will alter food production in future ${ }^{[52,53]}$. Climate-stress resistant cultivars, and adopting conservation and mitigation strategies as well as use of weather forecasting can reduce these risks ${ }^{[31,54]}$.

\subsection{GHG emission}

GHG emission is another challenge for agriculture. In the absence of preventative measures, the estimated global emissions of GHGs will increase by about $30 \%$ in 2030 and $87 \%$ in 2050 from 2010 levels (Fig. 2) ${ }^{[24,54]}$. Measures include reducing excessive usage of nutrients by conservation agriculture and improving productivity ${ }^{[31,54]}$. Environmental pollution due to excessive usage of nutrients like $\mathrm{N}$ and $\mathrm{P}$, reduction in water reservoirs and GHG emissions, and consequently climate change, are products of intensive agriculture ${ }^{[24]}$. The increasing demands of 9 billion people could increase the environmental consequences of food production systems by $50 \%$ to $90 \%$, if timely and systematic measures are not taken to keep the earth safe for humanity. It is suggested that adopting the green food option, with less food loss in the food chain, is needed. It is beneficial and essential that humans use a synergistic combination of many measures to sustain life $\mathrm{e}^{[24,55]}$.

\subsection{Natural resources}

Macro nutrients (NPK) are available to plants in ample amount due to continuous application of fertilizer ${ }^{[56]}$ but micronutrients (e.g., B, Fe, Mo, Zn) deficiency in crops could become a challenge for the future. Water is essential for plant development, but climate change will cause disturbance and move water away from root zones. Adaptive technologies, e.g., drip irrigation or sprinkler irrigation, are good options that can be introduced to respond to this challenge.

\subsection{Aquaculture}

Demand for seafood is increasing daily and will reach $80 \mathrm{Mt}$ by 2030 . This is also a serious challenge for water scarcity, and consumer preferences. Untreated water effluents in fresh water are a big challenge for the aquaculture industries. Also, temperature extremes are a serious issue for marine biodiversity ${ }^{[57]}$.

\subsection{Food storage}

Storage is an important factor to ensure food security because in China, 40\%-50\% of total food production is being lost (Fig. 3) due to poor storage conditions at farmer household stores as well as warehouses ${ }^{[58]}$. Storage ensures the quality of farm products by protecting them from deterioration for a specific time span and also beyond normal shelf life ${ }^{[59]}$. Lack of facilities, technology transfer, technical services and support, as well as knowledge about storage are the main challenges that seriously affect the performance of farmers in developing countries ${ }^{[59]}$. Storage depends on the end utilization of produce (food, feed/forage, and seed $)^{[60,61]}$. The farmer must be aware of storage requirements of perishable, semi perishable and stable food required to ensure a quality product. Various types of storage structure are being used to store foods (vegetables, fruits, dry fruits, livestock products, etc.) ${ }^{[62]}$. Generally, structures need to be kept cool (refrigerator, or at least ventilated and shaded) and importantly, food stored must be of initially good quality. Farmers are using various methods of storage according to their needs ${ }^{[59,63]}$ but 
restoration of storage systems is needed for global food security. Some of the storage methods are discussed below.

\subsubsection{On farm storage}

Farming communities store their surplus produce on the farm for several months. They build storage granaries (jars, silos) and they have to treat the produce with plant extracts to control the pest damage ${ }^{[64]}$. Simple, low budget storage methods can hugely cut food losses, mainly for small growers in developing countries, who face food losses due to pests, biological decay, and transportation damages ${ }^{[60]}$. According to FAO, the local metal storage silos and use of plastic crates instead of plastic bags can reduce food loss during food storage in developing countries in an ecofriendly way ${ }^{[58]}$. Additionally, field storage clamps can be used to store roots and tubers for a short time ${ }^{[58,64]}$. Fresh cassava tubers deteriorate rapidly after harvest and is best to keep unharvest until required ${ }^{[61]}$. Simple improvements in farm storage by updating old structures to control pests may be applicable than constructing new storage structures.

\subsubsection{Warehouse storage}

Food warehouses (dry storage, cold storage, and chilled storage) are valuable connection between farmer's field, processor, retailer and consumer, and require a strict evaluation for proper operation ${ }^{[64,65]}$. Warehouses are generally operated and owned by government departments and store sufficient quantities for future or emergency use $^{[37,50]}$. Warehouses require high capital inputs to store the food for longer period, along with issues such as land acquisition cost and labor scarcity. The warehouse shortage issue can be managed by inviting private companies in order to allow others to support the goals of food security ${ }^{[50]}$. Food possibly spoils in warehouse as a consequences of pest attack and biological changes (respiration and rancidity development). Decay of food depends on composition, humidity and temperature of storage ${ }^{[66,67]}$. In warehouse, for successful storage of roots, tubers and other foods, it is necessary always to select high quality products with no physical damage or pest attack. Many growers do not store fresh products but keep them in the ground until required. Some researchers consider processing as an integral part of storage to extend food availability beyond the area and season of production $^{[68,69]}$. This helps to stabilize food supplies and diversity of nutrients, ensuring food security at national and international level.

According to FAO, proper storage not only affects food availability but also causes a significant decrease in food production, which is obvious from the example of potato growers in Cameroon. Potato farmers grow only as much potato as they can sell in markets before the monsoon and they are forced to leave any surplus to rot ${ }^{[61,70]}$. In contrast, if high storage facilities are available, huge losses can be minimized and availability of products will increase. In this way, storage can help solve global food security problem $^{[70]}$.

\subsection{Food processing}

Food processing is a sector encompassing the use of various raw material, processes and production of end products. It ranges from very simple (e.g., selling fresh carrots) to multifaceted (e.g., carrots that are washed, cut and packed to sell to food processors making sauces and stews to sell to caterers making individual sized meals to sell in supermarkets or for airline catering $)^{[71,72]}$. Raw materials used in food and beverage industries are of farm origin and are produced from the limited resources of land, water and energy, using manufactured inputs such as fertilizers, pesticides and cleaning agents. Environmental issues related to food processing are biodiversity reduction (monocultures), N, P and S scarcity, heavy metal toxicity, generation of wastewater, packaging wastes, organic residues and air toxins (i.e., volatile organic compounds, particulate matter, GHGs, odors, and CFCs $)^{[72]}$. These contrast with diet choice, animal health, worker lifestyle, and social and economic conditions, which are considered as non-environmental issues. Food processing has fewer environmental impacts than farming ${ }^{[73]}$, because processors are regulated by law or respond to their own interest based on reports and surveys from the food chain to reduce inputs, energy, and water that has cost savings advantages and consequent environmental benefits ${ }^{[57]}$.

The ever-increasing population requires the production of $70 \%$ more food, which can be achieved by innovative green technologies such as green food processing (Fig. 3). Green food processing was presented on the basis of green chemistry and green engineering that comprises the discovery and design of technical processes which will reduce use of energy and water, favors bio-refinery to recycle the products, and guarantees product safety and quality products $^{[72]}$.

\subsubsection{Green food processing techniques}

Foods processing is necessary to ensure food safety and increase shelf life. Various techniques are used to transform raw products into valuable product (Fig. 3). Primary processing methods are washing, sorting, dehulling and milling of plant-based products and, for animals, harvesting of eggs; heading, deheading, gutting, filleting, scaling, chilling, freezing, washing of fish products; salting, homogenization and pasteurization of milk; slaughter, dressing, boning acidification, salting, brining, smoking, thermal processing, refrigeration, and storage of meat. 
Secondary and tertiary handling practices are further used to transform food products into other value-added food items ${ }^{[72]}$. With the implementation of green food technologies, food processing including transformation, extraction and preservation have enabled contents of natural ingredients in foods to be preserved.

Food enzymes are an advanced option to process food and provide benefits of specificity, sensitivity, non-toxicity, high activity at low concentration and with ease of inactivation. Enzyme techniques are environmentally friendly and fit for green food due to the mild treatments conditions compared to other methods ${ }^{[74]}$, and results in long shelf life, improved texture, flavors and yield ${ }^{[72,74]}$. Enzymes used in green technologies include carbohydrases (e.g., amylases, pectinases, cellulases, galactosidases and chitinases), lipases (e.g., pancreatic lipase and phospholipases), proteases (e.g., pepsins, trypsins, bromelain, papain, amylases and cellulases), isomerases (e.g., glucose isomerase); transferases (e.g., transglutaminases) and oxidoreductases (e.g., glucose oxidase and polyphenol oxidase ${ }^{[72]}$. Enzyme technologies also includes enzyme engineering to produce enzymes with superior qualities such as high $\mathrm{pH}$ tolerance, storage and temperature stability and reusability. Many thermal techniques are already in use to refine food products but are energy intensive and there is a need to focus energy-efficient methods to protect the environment. Innovative methods that can be used in green food process are microwave and radio-frequency heating including microwave extraction, solvent free microwave hydro distillation (to extract essential oils), microwave hydro diffusion and gravity to tenderize the meat, pulsed electric fields or electropermeabilization, high pressure processing, ionizing radiation, ohmic heating, treatment with ultraviolet light, ozonization $^{[72,75]}$, instant controlled pressure drop technology, super critical fluids as alternative solvents ${ }^{[76-78]}$. These technologies are based on reduced energy and water consumption.

\subsubsection{Drying}

Drying is an important part of processing and a main target of green technology because of the high energy costs. Drying is used to protect texture, improve shelf life and reduce transportation costs. Wet feed pretreatment, drying, retrieval of dried products, and heat recovery from exhaust gases are elements of drying. To lessen energy consumption $^{[79]}$, initial moisture content of the wet feed should be reduced by pressing, membrane separation, filtration, centrifugation, coagulation or sedimentation prior to the drying process. For example, osmotic dehydration is used as a preheat treatment operation or as a final dehydration step $^{[72,80]}$. Heating of wet feed at a high temperature using energy-efficient means can also help to reduce overall energy use. Moreover, use of eco-friendly energy sources and drying installations and maximum use or recycling of different waste streams and byproducts are useful options ${ }^{[72,79]}$. Likewise, to regulate environmental pollution, efficient systems having the ability to recover energy, particulates and GHGs from exhaust gases must be considered (Fig. 3). Transformation from carbon-based energy to solar, hydro and wind sources is important for green food production to protect the environment by minimal releases of GHGs.

\subsubsection{Packing}

Packing, another important element of the food chain that affects choice, safety and quality of the green food products, is also a way of communication between producers and consumers. Suitable packing is crucial for the quality of products as substandard packing will reduce product quality and excessive packing will impose a burden on the environment. Green food technologies required green packaging with high functionality, minimal use of materials and maximal use of recycled safe and nontoxic materials ${ }^{[72,81]}$.

\subsubsection{Reducing process-induced toxins in foods}

High temperature and pressure used in processing can generate toxins (nitrosamines, heterocyclic aromatic amines, acrylamide, furans, polyaromatic hydrocarbons, and bisphenol ${ }^{[72,82]}$. Green processing technology may be a key option for reducing toxins in foods and preventing their formation under processing conditions. Processinduced toxins can be reduced by adopting suitable formulations, breeding quality cultivars, improved cooking conditions (microwave), and using appropriate utensils and containers in processing.

\subsection{Transportation along the food chain}

Transportation is a key component of the food chain and a main contributor to GHG emissions in developing countries. In North America, the estimated average distance food travels by road or sea from farm to consumer is $2000 \mathrm{~km}^{[83]}$, and this type of food transport includes ships, trains and trucks and requires proper packing ${ }^{[84]}$. According to Weber and Matthews ${ }^{[85]}$, trans border shipments emit less GHGs followed by inland water and train/road (10 times more) and air (40 times more). Selection of mode of transport depends on food packing, provision to consumer and the food chain. Depending on products and processes, the impact of transportation on GHGs range from less than 5\% to more than 50\% (lower percentage values are generally found with products 
already generating large GHG emissions from farming and processing, e.g., milk powder ${ }^{[72]}$.

\section{Conclusions}

Meeting the rising demands of 9 billion people could increase the environmental consequences of food system by almost $50 \%-90 \%$, if timely and systematic measures are not taken to keep the earth safe for humanity. There is a need to adopt green food options with less food loss in the food chain. It is beneficial and essential that humans use a synergistic combination of many measures to sustain life, instead of only one option. Green food has the potential to solve many problems of food security in China and ultimately worldwide. Green food innovation has already resulted in millions of hectares being green food certified and this is increasing rapidly. Consumers are willing to pay for green food, but building trust in the certification and processing system has to be considered. To promote the consumption of green food in China, the government should strengthen the enforcement of the certification system to build the trust of consumers in certified green food. Green food labeling not only provides information between consumers and producers, but also promotes more sustainable and ethical business practices. During this process, effectiveness, efficiency and equity should be simultaneously addressed so that the best results can be achieved. Ecological citizenship which can improve environmental values may be a powerful motivating force for sustainable consumption behavior. Chinese consumers are giving increasing attention to the environmental issues but more education is needed to promote environmental awareness or environmental values. The environmental costs of the current food system and the disproportionate contribution of animal-based food items to these costs are by now firmly established.

To meet the food demand of the predicted global population, future challenges of food production must be met by adopting green food technologies as well as by valuing food by stopping or minimizing losses and wastage in the food chain. Improvements in storage of foods can cut the ample food loss to solve the food security issue. Due to its minimal releases of GHGs, transformation from carbon-based energy to solar, hydro and wind sources are needed for green food production to protect the environment. Suggested green strategies for enhancing food production while alleviating environmental burdens include food loss control by increasing green agricultural productivity, producing animal-based foods on marginal lands and from byproducts, improving processing and shifting toward plant-based diets (it is easy to provide direct food to humans instead of indirect food by feeding animals, and it will reduce GHG emissions in a different way).
Compliance with ethics guidelines Mahmood ul Hassan, Xin Wen, Jiuliang Xu, Jiahui Zhong, and Xuexian Li declare that they have no conflicts of interest or financial conflicts to disclose.

This article does not contain any studies with human or animal subjects performed by any of the authors.

\section{References}

1. Marchesini S, Hasimu H, Spadoni R. An overview of the organic and green food market in China. In: Hass R, Canavari M, Slee B, Tong C, Anurugsa B, eds. Looking east looking west: organic and quality food marketing in Asia and Europe. Wageningen: Wageningen Academic Publishers, 2010, 155-171

2. Qi X, Ploeger A. Explaining consumers' intentions towards purchasing green food in Qingdao, China: the amendment and extension of the theory of planned behavior. Appetite, 2019, 133: 414-422

3. Yu X, Gao Z, Zeng Y. Willingness to pay for the "green food" in China. Food Policy, 2014, 45: 80-87

4. Lin L, Zhou D, Ma C. Green food industry in China: development, problems and policies. Renewable Agriculture and Food Systems, 2010, 25(1): 69-80

5. Sanders R. A market road to sustainable agriculture? Ecological agriculture, green food and organic agriculture in China. Development and Change, 2006, 37(1): 201-226

6. Yin S, Wu L, Du L, Chen M. Consumers' purchase intention of organic food in China. Journal of the Science of Food and Agriculture, 2010, 90(8): 1361-1367

7. Sirieix L, Kledal P R, Sulitang T. Organic food consumers' tradeoffs between local or imported, conventional or organic products: a qualitative study in Shanghai. International Journal of Consumer Studies, 2011, 35(6): 670-678

8. China Green Food Development Center (CGFDC). Green Food Statistical Yearbook. Beijing: CGFDC, 2018 (in Chinese)

9. China Green Food Development Center (CGFDC). The Second Session: What Is the Green Food Label? Available at the CGFDC website on December 20, 2018 (in Chinese)

10. Jiang Y, Wang H H, Jin S, Delgado M S. The promising effect of a green food label in the new online market. Sustainability, 2019, 11 (3): 796

11. China Green Food Development Center (CGFDC). Green Food Statistical Yearbook. Beijing: CGFDC, 2017 (in Chinese)

12. Dong Y, Han X, Bian Y, Liu Z. Analysis of environmental ecological risk in agricultural production - a case study on the construction planning of 50 billion kilograms grain production capacity of Heilongjiang Province. Heilongjiang Science and Technology of Water Conservancy, 2009, 37(5): 85-86 (in Chinese)

13. Cheng X. Hard and Soft Constraints for China to Sustain Agricultural Development and to Follow the Conventional Modernization Approach of Agriculture and Deserved Alternative Way' in Integrated Resource Management for Sustainable Agriculture CIAD. Beijing: Beijing Agricultural Press, 1994, 407-415 (in Chinese)

14. Li Z. Organic Agriculture, a Global Perspective: the Challenges and 
Opportunities for China. In: Proceedings of the First International Symposium on Organic Farming in China. Beijing: Beijing Agricultural University Press, 1994, 35-41

15. Cheng X, Han C R, Taylor D. Sustainable agricultural development in China. World Development, 1992, 20(8): 1127-1144

16. Sanders R. Prospects for Sustainable Development in the Chinese Countryside: The Political Economy of Chinese Ecological Agriculture (Routledge Revivals), 1st ed. Aldershot: Ashgate Publishing, 2000, 239

17. Thiers P. China and Global Organic Food Standards: Sovereignty Bargains and Domestic Politics. In: Bingen J, Busch L, eds. Agricultural Standards: The Shape of The Global Food and Fiber System. New York: Springer, 2006, 193-217

18. Ministry of Agriculture of China. China Green Food Standards and Technology Committee of the Ministry of Agriculture (n.d.) 'Certification Guidelines for AA Green Food'. Beijing: Ministry of Agriculture of China, 2000

19. Ho P. Greening without conflict? Environmentalism, NGOs and civil society in China. Development and Change, 2001, 32(5): 893921

20. Willett W C, Stampfer M J. Current evidence on healthy eating. Annual Review of Public Health, 2013, 34(1): 77-95

21. Organisation for Economic Co-operation and Development (OECD). A Green Growth Strategy for Food and Agriculture: Preliminary Report. OECD, 2011

22. Stevens C. OECD Consultant Report 2011: Agriculture and Green Growth, Available at OECD website on August 10, 2019

23. Vermeulen S J, Campbell B M, Ingram J S I. Climate change and food systems. Annual Review of Environment and Resources, 2012, 37(1): 195-222

24. Springmann M, Clark M, Mason-D'Croz D, Wiebe K, Bodirsky B L, Lassaletta L, de Vries W, Vermeulen S J, Herrero M, Carlson K M, Jonell M, Troell M, DeClerck F, Gordon L J, Zurayk R, Scarborough P, Rayner M, Loken B, Fanzo J, Godfray H C J, Tilman D, Rockström J, Willett W. Options for keeping the food system within environmental limits. Nature, 2018, 562(7728): 519 525

25. Alexandratos N, Bruinsma J. World Agriculture Towards 2030/ 2050: The 2012 Revision. Rome: FAO, 2012

26. Organisation for Economic Co-operation and Development (OECD). Promoting sustainable consumption: good practices in OECD countries. OECD, 2008

27. Paull J. The Greening of China's Food - Green Food, Organic Food and Eco-Labelling, Sustainable Consumption and Alternative AgriFood Systems Conference (SUSCONS). Arlon: Liege University, 2008

28. Minister of Agriculture of the People's Republic of China. Quality and Safety of Agricultural Products. Available at China Development Gateway website (Report, 2007) on December 20, 2018

29. Liu Q, Yan Z, Zhou J. Consumer choices and motives for ecolabeled products in China: an empirical analysis based on the choice experiment. Sustainability, 2017, 9(3): 331

30. Cervantes-Godoy D, Dewbre J. Economic Importance of Agriculture for Poverty Reduction. In: OECD Food, Agriculture and Fisheries Working Papers, No. 23. Paris: OECD publishing, 2010

31. Organisation for Economic Co-operation and Development
(OECD). Agricultural Policies and Rural Development: A Synthesis of Recent OECD Work. OECD, 2010

32. Wang Y. JD.com Invests $\$ 700$ Million In Chinese Supermarket Chain Yonghui 2015. Available at Forbes website on December 20, 2018

33. Wingfield N, Merced M J D. Amazon to Buy Whole Foods for $\$ 13.4$ Billion. Available at New York Times website on December 20, 2018

34. eMarketer. Worldwide Retail Ecommerce Sales: eMarketer's Updated Estimates and Forecast Through 2019. Available at eMarketer website on December 20, 2018

35. China Internet Network Information Center (CINIC). The 41th Statistical Report on Internet Development in China. Beijing: CINIC, 2018

36. China Internet Network Information Center (CINIC). Online Market Report of China in 2015. Beijing: CINIC, 2016

37. Food and Agriculture Organization of the United Nations (FAO). Global Food Losses and Food Waste: Extent, Causes and Prevention, 2011. Available at FAO website on December 20, 2018

38. Hall K D, Guo J, Dore M, Chow C C. The progressive increase of food waste in America and its environmental impact. PLoS One, 2009, 4(11): e7940

39. Buzby J C, Hyman J. Total and per capita value of food loss in the United States. Food Policy, 2012, 37(5): 561-570

40. Shepon A, Eshel G, Noor E, Milo R. The opportunity cost of animal based diets exceeds all food losses. Proceedings of the National Academy of Sciences of the United States of America, 2018, 115(15): 3804-3809

41. Gooch M V, Felfel A. Food Waste in Canada $-\$ 27$ Billion Revisited. Available at Value Chain Management Center website on December 20, 2018

42. McCarthy B, Liu H B. Food waste and the 'green' consumer. Australasian Marketing Journal, 2017, 25(2): 126-132

43. Melikoglu M, Lin C S K, Webb C. Analysing global food waste problem: pinpointing the facts and estimating the energy content. Central European Journal of Engineering, 2013, 3(2): 157-164

44. Foley J A, Ramankutty N, Brauman K A, Cassidy E S, Gerber J S, Johnston M, Mueller N D, O'Connell C, Ray D K, West P C, Balzer C, Bennett E M, Carpenter S R, Hill J, Monfreda C, Polasky S, Rockström J, Sheehan J, Siebert S, Tilman D, Zaks D P M. Solutions for a cultivated planet. Nature, 2011, 478(7369): 337-342

45. Cassidy E S, West P C, Gerber J S, Foley J A. Redefining agricultural yields: from tonnes to people nourished per hectare. Environmental Research Letters, 2013, 8(3): 034015

46. Hedenus F, Wirsenius S, Johansson D J A. The importance of reduced meat and dairy consumption for meeting stringent climate change targets. Climatic Change, 2014, 124(1-2): 79-91

47. Shepon A, Eshel G, Noor E, Milo R. Energy and protein feed-tofood conversion efficiencies in the US and potential food security gains from dietary changes. Environmental Research Letters, 2016, 11(10): 105002

48. Eshel G, Shepon A, Noor E, Milo R. Environmentally optimal, nutritionally aware beef replacement plant-based diets. Environmental Science \& Technology, 2016, 50(15): 8164-8168

49. Funabashi M. Human augmentation of ecosystems: objectives for 
food production and science by 2045. Npj Science of Food, 2018, 2 (1): 16

50. Godfray H C J, Beddington J R, Crute I R, Haddad L, Lawrence D, Muir J F, Pretty J, Robinson S, Thomas S M, Toulmin C. Food security: the challenge of feeding 9 billion people. Science, 2010, 327(5967): 812-818

51. Parry M L, Canziani O F, Palutikof J P, van der Linden P J, Hanson C E. Contribution of Working Group II to the Fourth Assessment Report on Climate Change. In: IPCC Fourth Assessment Report: Climate Change 2007. Cambridge: Cambridge University Press, 2007

52. Wheeler T, von Braun J. Climate change impacts on global food security. Science, 2013, 341(6145): 508-513

53. Paterson R R M, Lima N. How will climate change affect mycotoxins in food? Food Research International, 2010, 43(7): 1902-1914

54. Wreford A, Moran D, Adger N. Climate Change and Agriculture: Impacts, Adaptation and Mitigation. Paris: Organisation for Economic Co-operation and Development (OECD), 2010

55. Beachy R N. Building political and financial support for science and technology for agriculture. Philosophical Transactions of the Royal Society of London. Series B, Biological Sciences, 2014, 369(1639): 20120274

56. Keyzer M A, van Veen W V, Voortman R L, Huang J, Qiu H, Fischer G, Ermolieva T. Nutrient Shortages and Agricultural Recycling Options Worldwide, With Special Reference to China. Amsterdam: Stichting Onderzoek Wereldvoedselvoorziening (SOW), 2009, 20 (CATSEI project paper)

57. Babcock R C, Bustamante R H, Fulton E A, Fulton D J, Haywood M D E, Hobday A J, Kenyon R, Matear R J, Plagányi E E, Richardson A J, Vanderklift M A. Severe continental-scale impacts of climate change are happening now: extreme climate events impact marine habitat forming communities along $45 \%$ of Australia's coast. Frontiers in Marine Science, 2019, 6: 411

58. Food and Agriculture Organization of the United Nations (FAO). The State of Food and Agriculture, Climate Change, Agriculture and Food Security. Available at the FAO website on December 20, 2018

59. Joardder M U H, Masud M H. Challenges and Mistakes in Food Preservation. In: Food Preservation in Developing Countries: Challenges and Solutions. UK: Springer International Publishing, 2019

60. Hodges R J, Buzby J C, Bennett B. Postharvest losses and waste in developed and less developed countries: opportunities to improve resource use. Journal of Agricultural Science, 2011, 149(S1): 37-45

61. Zorya S, Morgan N, Diaz Rios L, Hodges R, Bennett B, Stathers T, Mwebaze P, Lamb J. Missing food: the case of postharvest grain losses in Sub-Saharan Africa. Washington: The Word Blank, 2011

62. Acedo A J L. Postharvest technology for leafy vegetables. Tainan: AVRDC-The World Vegetable Center, 2010

63. Shajil S, Mary A, Rani J C E. Recent food preservation techniques employed in the food industry. In: Patra J K, Das G, Shin H S, eds. Microbial biotechnology. Singapore: Springer, 2018, 3-21

64. Sutton A O, Strickland D, Norris D R. Food storage in a changing world: implications of climate change for food-caching species. Climate Change Responses, 2016, 3(1): 12
65. Boonsumrej S, Chaiwanichsiri S, Tantratian S, Suzuki T, Takai R. Effects of freezing and thawing on the quality of tiger shrimp (Penaeus monodon) frozen by air-blast and cryogenic freezing. Journal of Food Engineering, 2007, 80(1): 292-299

66. Cowell N D. Storage, Handling and Packaging. In: Ranken M D, Kill R C. Food Industries Manual. Boston: Springer, 1993, 482-536

67. Kirigia D, Winkelmann T, Kasili R, Mibus H. Development stage, storage temperature and storage duration influence phytonutrient content in cowpea (Vigna unguiculata L. Walp.). Heliyon, 2018, 4 (6): e00656

68. Augustin M A, Riley M, Stockmann R, Bennett L, Kahl A, Lockett T, Osmond M, Sanguansri P, Stonehouse W, Zajac I, Cobiac L. Role of food processing in food and nutrition security. Trends in Food Science \& Technology, 2016, 56: 115-125

69. Rillig M C, Lehmann A, Lehmann J, Camenzind T, Rauh C. Soil biodiversity effects from field to fork. Trends in Plant Science, 2018, 23(1): 17-24

70. Joris T, Candel J. Reducing food wastage, improving food security? The Netherlands: Food \& Business Knowledge Platform, 2014

71. Hunt R G, Franklin W E, Hunt R G. LCA-how it came about? International Journal of Life Cycle Assessment, 1996, 1(1): 4-7

72. Boye J I, Arcand Y. Current trends in green technologies in food production and processing. Food Engineering Reviews, 2013, 5(1): $1-17$

73. Arcand Y, Maxime D, Zareifard R. LCA of processed food. In: Boye J I, Arcand Y, eds. Green technologies in food production and processing. New York: Springer, 2012, 115-148

74. Simpson B K, Xin R, Jiang X J. Enzyme-assisted food processing. In: Boye J I, Arcand Y, eds. Green technologies in food production and processing. New York: Springer, 2012, 327-361

75. Ngadi M O, Latheef M B, Kassama L. Emerging technologies for microbial control in food processing. In: Boye J I, Arcand Y, eds. Green technologies in food production and processing. New York: Springer, 2012, 363-411

76. Mounir S, Besombes C, Al-Bitar N, Allaf K. Study of instant controlled pressure drop DIC treatment in manufacturing snack and expanded granule powder of apple and onion. Drying Technology, 2011, 29(3): 331-341

77. Mounir S, Allaf T, Berka B, Hassani A, Allaf K. Instant controlled pressure drop technology: from a new fundamental approach of instantaneous transitory thermodynamics to large industrial applications on high performance-high controlled quality unit operations. Comptes Rendus. Chimie, 2014, 17(3): 261-267

78. Chemat F, Rombaut N, Meullemiestre A, Turk M, Perino S, Fabiano-Tixier A S, Abert-Vian M. Review of green food processing techniques. Preservation, transformation, and extraction. Innovative Food Science \& Emerging Technologies, 2017, 41: 357377

79. Grabowski S, Boye J I. Green technologies in food dehydration. In: Boye J I, Arcand Y, eds. Green technologies in food production and processing. New York: Springer, 2012, 413-441

80. Grabowski S, Marcotte M. Pretreatment efficiency in osmotic dehydration of cranberries. In: Chanes J W, Velez-Ruiz J F, BarbosaCanovas G V, eds. Transport phenomena in food processing. Boca Raton: CRC Press, 2003

81. Selke S E M. Green packaging. In: Boye J I, Arcand Y, eds. Green 
technologies in food production and processing. New York: Springer, 2012, 443-468

82. Akhtar H. Reducing process-induced toxins in foods. In: Boye J I, Arcand Y, eds. Green technologies in food production and processing. New York: Springer, 2012, 571-605

83. Pirog R S, Van Pelt T, Enshayan K, Cook E. Food, fuel and freeways: an Iowa perspective on how far food travels, fuel usage, and greenhouse gas emissions. Leopold Center Publications and
Papers, 2001

84. Wakeland W, Cholette S, Venkat K. Transportation issues and reducing the carbon footprint. In: Boye J I, Arcand Y, eds. Green technologies in food production and processing. New York: Springer, 2012, 211-236

85. Weber C L, Matthews H S. Food-miles and the relative climate impacts of food choices in the United States. Environmental Science \& Technology, 2008, 42(10): 3508-3513 